\title{
EPUB3 Based Mathematical E-Modules Using the Sigil Application as A Solution in Teaching and Learning Process Through Covid-19 Pandemic
}

\author{
Rahmi Ramadhani ${ }^{(*)}$, Yulia Fitri \\ Universitas Potensi Utama, JL. K.L. Yos Sudarso KM. 6,5 No. 3-A Tanjung Mulia, \\ Medan, Sumatera Utara, Indonesia
}

Received: July 30, 2020

Revised: February 03, 2021

Accepted: February 09, 2021

\begin{abstract}
The aim of this study was to develop an EPUB3-based mathematics EModule using a valid and effective SIGIL application for high school students in Medan, Sumatera Utara. This research was a research and development $(R \& D)$ study with the ASSURE model consisting of 6 stages, including analyzing learners-state objectives; select method; media and materials; utilize media and materials; require participant learner; evaluate and revise. The subjects of the study were XI grade senior high school students in Medan, Sumatera Utara, Indonesia. The results showed that the EPUB3-based mathematical E-module was valid and reliable for the use in the learning process based on the results of expert validation, with an average value of 3.77 and included in good categories. Furthermore, EPUB3-based Mathematics E-Modules are used in the online learning process, especially in statistical material. Student respondent test results showed that $58 \%$ of students felt helped in understanding the material using the EPUB3-based Mathematics E-Modules during online learning. Students more easily learn the material anywhere and anytime and also can test the ability related to statistical material directly on the E-Module to get the final result whether it meets the Minimum Completeness Criteria (KKM) or not. The EPUB3-based Math E-Modules using the SIGIL application is proven to be valid and effective in helping students and teachers carry out online learning during the Covid-19 pandemic.
\end{abstract}

Keywords: E-Modules, Mathematics, EPUB3, SIGIL Online Learning, Covid-19

(*) Corresponding Author:

rahmiramadhani3@gmail.com, 081262900365

How to Cite: Ramadhani, R. \& Fitri, Y. (2021). EPUB3 based mathematical e-modules using the Sigil application as a solution in teaching and learning process through covid-19 pandemic. Formatif: Jurnal Ilmiah Pendidikan MIPA, 11 (1): 35-48. http://dx.doi.org/10.30998/formatif.v11i1.6826

\section{INTRODUCTION}

Technology in the learning process is not a new topic in the world of education, especially high school education. Technology has often been applied in the learning process, such as GeoGebra, Autograph, Desmos, Cabri-3D which are used in mathematics learning; Duolingo is used in learning English, to the most frequently used namely Microsoft Power Point and Macromedia Flash in almost all learning. Technology plays a dual role in the learning process. In the teacher's perspective, technology plays a role in helping the teacher as a medium in transferring information to students, as well as a visual learning support tool. While in the perspective of students, technology acts as a medium in helping students understand abstract concepts and material, by changing it to become more visual. This helps students to understand and apply the concept in solving problems.

The important role of technology in learning affects in improving the quality of education. The technology not only can be used as a medium or learning support tool but 
also can be used in every other part of the educational process, from implementation to evaluation of learning (Al-Hariri \& Al-Hattami, 2017; Burroughs et al., 2019). Learning and teaching using technology is one good strategy in organizing the concept of implementation to the evaluation of the education system (Qurat-ul-Ain et al., 2019). The use of technology in learning indicates that the learning process requires supporting tools and facilities that can provide new experiences for students and increase their motivation (Lestari et al, 2020). The need for technology is increasingly high when the learning process is no longer done through face-to-face system but is conducted virtually or often referred as learning in the network (e-learning). E-Learning provides opportunities for students to learn anywhere and anytime. Technology facilitates students to improve new skills one of which is the use of technology (Bawa, 2016; Sadeghi, 2019). The application of e-learning also can improve the communication skills between teachers and students (Grabinski et al., 2020).

Online-based distance learning (e-learning) has increasingly developed a variety of different techniques and strategies. This phenomenon becomes higher in advancement as the Covid-19 pandemic is increasingly widespread throughout the world, including in Indonesia. The emergence of the COVID-19 pandemic requires face-to-face learning be transformed into distance learning using technological assistance. Distance learning using technological assistance is one of the efforts made to protect students, teachers and all elements of society in the educational environment from the spread of COVID-19. This effort raises the fact that technology plays a role not only as a medium but also as a substitute for a face-to-face learning process that cannot be done (Allen et al., 2020; Murphy, 2020; Zhang et al., 2020). This phenomenon proves that technology can help teachers, students and the education system to continue to run the learning process, although it is not in a face-to-face process in the classroom.

Distance learning is an alternative so that students and teachers continue to carry out learning and achieve the expected learning outcomes. In increasing the capacity to teach virtually, the teacher must utilize asynchronous learning that can utilize technology in the learning process (Daniel, 2020; Dhawan, 2020). One use of technology dealing with virtual learning is to develop technology-based teaching materials or also called the E-Module (Electronic Module). E-Modules are developed following the material that will be taught to the students. E-Modules consists of teaching materials to the evaluation of learning outcomes that are designed hence students can input the answers directly to the E-Module and check the grades they obtained. However, the existing E-Modules so far only show the cognitive part, meaning that the self-evaluation activities and the scores obtained as part of feedback on students have never been developed in the E-Module. Matanluk et al. (2013) developed a CSAA-based E-Module by using a constructivism approach and highlighting the improvement of students' cognitive abilities. Nursolekah \& Suparman (2019) also developed a mathematical module, but it was only limited to describing the material and providing practice questions, without any visual display, pictures or supporting teaching videos applied in the module, and the module developed was also not an electronic-based module. Fonda \& Sumargiyani (2018) also developed a Mathematical E-Module but did not display teaching videos or score results obtained by students, whether they met the Minimum Mastery Criteria (KKM) or not.

Apart from the content and parts contained in the E-Module, the development of the E-Module is also carried out using a variety of applications, such as using the Kvisoft Flipbook Maker Pro application (Fonda \& Sumargiyani, 2018; Linda et al., 2018; Wahyuni et al., 2018); using the Book Digitization application (Asrial et al., 2019); using the Adobe Flash CS6 application (Fauziah et al., 2016); to use the Macromedia Flash application (Pradina \& Suyatna, 2018; Syahrul et al., 2019). In addition to these applications, there are also other applications, namely the SIGIL application as an application for making 
electronic modules (e-modules) and electronic books (e-books). Sari (2016) in her research uses the SIGIL application in developing digital books in the subjects of Cookies and Candies. The same thing was done by Darma et al., (2019); Ramadhani \& Fitri (2020a) that used the SIGIL application in developing e-modules.

The use of e-modules in the learning process provides advantages, one of which is the teacher can control students learning process in digital-based. The teacher can provide instruction not only in the classroom but also can be continued outside the classroom. The teacher can also control the content of teaching materials that are appropriate to the level of students' abilities and according to the competencies expected by the Curriculum (Tsai et al., 2017). Utilization of e-modules that combine technology development and learning provides new learning experiences and builds student knowledge (Jaenudin et al., 2017). Based on this description, the researchers conducted a study by developing a mathematics e-module based on EPUB3 using the SIGIL application. The SIGIL application is selected because it uses the HTML programming language. In addition, the SIGIL application provides facilities to input teaching videos in MP4 format and can input audio in MP3 format.

There are benefits to the use of e-modules in the learning process, one of which is that the teacher can control the learning process for digital-based students. Teachers can not only provide instruction in the classroom, but also outside the classroom. New learning opportunities and student awareness are generated through the use of e-modules that merge technology creation and learning (Jaenudin et al., 2017). The use of e-modules also offers individual learning opportunities for students so that they can learn to solve problems in their own way. Learning with e-modules also makes learning easier to implement, since it can be used not only when the learning process is face-to-face (face-to-face learning) in the classroom, but also anywhere and at any time (Hamzah \& Mentari, 2017). E-module also can use in the e-learning format. Üzela \& Özdemira (2012)have learned that the use of elearning in learning is effective in improving positive attitudes and mathematical skills of teachers of mathematics. Freiman et al. (2017), Setyaningrum (2018), Ramadhani et al. (2019) and Ramadhani (2020) demonstrate that the implementation of e-learning (computer and technology) has a real effect on helping learners understand math problems in real contexts.

\section{METHODS}

This study uses a type of research development (R \& D) with the ASSURE design model consisting of 6 stages, including; analyze learners; state objectives; select methods, media and materials; utilize media and materials; require learner participant; evaluate and revise (Kim \& Downey, 2016). The ASSURE stages can be seen in Figure 1.

Based on fig.1, this research was started with analyzing learners for the first stage. Learners who are the subjects of this study are the second-degree students in senior high school and have the age range of 15-17 years. In accordance with the cognitive development theory developed by Piaget, the selection of students in this category is due to the student's age range already being at the level of formal operations (11 years and above). Students are at the highest stage of cognitive structure growth in the time of structured operations, where students are able to think objectively about all sorts of hypothetical problems, verbal problems, and can use scientific reasoning and consider the views of others. The curriculum and learning materials were checked in the second step to be relevant for the study. The results of the research indicate that the material in this research is Statistics which relevant in Curriculum 2013. Material that has been selected for the next to arrange and develop to get the learning tools, such as learning module. 


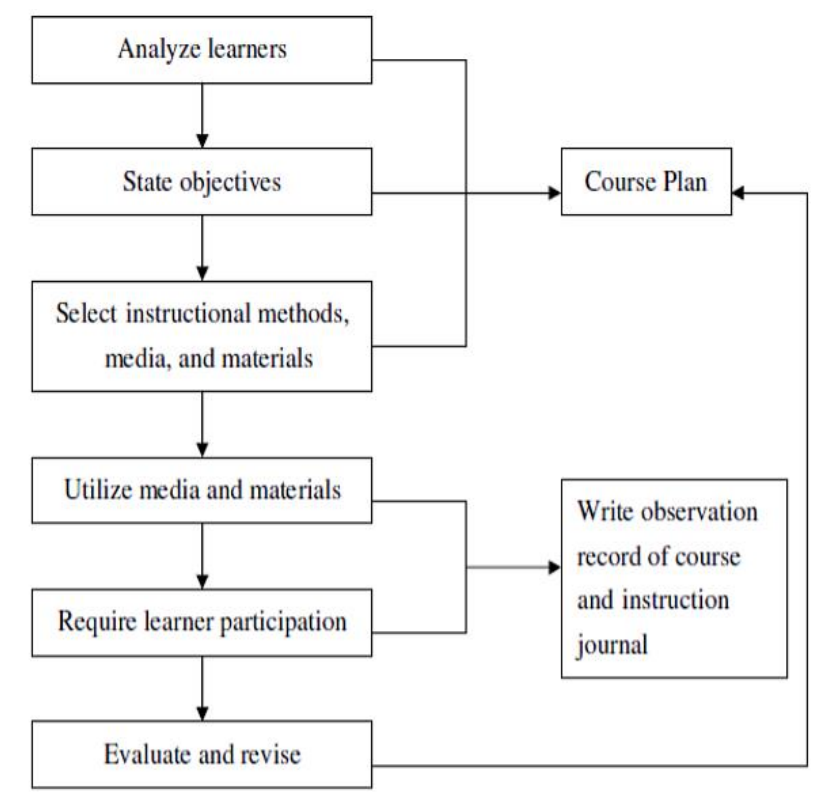

Figure 1. Stages of E-Module Development Model Using ASSURE Design

The researchers selected a module in digital format, called E-Module, to create the learning module. Researchers have designed and organized learning materials in the EModule (read: Statistics) consisting of a learning content overview (including learning video and several graphs that will help students understand the material), task practice, and students' peer review. In the other hand, researchers choose SIGIL application as software that used to created E-Module. SIGIL is an application for e-book and e-module manufacturers that uses the HTML programming language and can build EPUP2 or EPUB3 format books or electronic modules that can be read on computer operating systems such as Windows, OX X or Linux, and mobile operating systems such as Android. In addition, the SIGIL framework offers MP4 format video teaching input facilities and can input MP3 format audio (Figueiredo \& Bidarra, 2015). The choice of the SIGIL application as an application for the E-Module creator is also due to its fairly simple operation (Ramadhani \& Fitri, 2020b). All of these steps include in the third stage of ASSURE method.

The stages of developing EPUB3-based mathematical E-Modules using the SIGIL application are at the fourth stage, namely utilizing media and materials. At this stage, the Mathematical E-Module is prepared from the selection of teaching materials, teaching videos, supporting figures, to the matter of evaluating learning outcomes. Adjustment of material with basic competencies and learning outcomes is also carried out following the 2013 Curriculum. After the EPUB3-based mathematical E-Module prototype using the SIGIL application has been developed, the next step is to validate the contents of the EModule. Validation of E-Module content is carried out by experts in the field of educational technology and mathematics learning, as well as mathematics teachers. If the validation results indicate that the E-Module prototype is included in the good category, then the EModule mathematical prototype can be used in learning. However, it is necessary to finalize the E-Module prototype according to the revision results given by the validator. E-Module validated using the questionnaire form that consists of indicators of developing learning tools. The experts as validators checked the E-Module and offered advice to make these resources better than before and following the Curriculum 2013 standard. 
The final stage (require learner participant and evaluate-revise stage) is the application of EPUB3-based mathematics E-Modules developed using the SIGIL application for students. Mathematical E-Module is packaged in EPUB3 format and can be read through the EPUB reader application, namely Reasily (application on Android) and AZARDI (application on Desktop PC). At this stage, the research subjects used were second-year students at senior high schools in Medan, Sumatera Utara, Indonesia.

\section{RESULTS \& DISCUSSION}

\section{Results}

The E-Module was previously developed using three phases, based on the phases of the ASSURE process, there are analyzing students; stating objectives; choosing methods, media, and materials. In the first step, learners were tested about their skill and their level of mathematics knowledge. The student was selected as a study participant in the second grade of senior high school. In the second level, curriculum and learning materials have also been selected (state objectives). Statistics and E-Module are learning materials and resources used in this analysis (in the second and third stage).

In the fourth stage in the design development of ASSURE is utilizing media and materials. At this stage, the E-Module will be developed using the SIGIL application and designed in the EPUB3 format. The development results of the E-Module in EPUB3 format can be opened using the EPUB reader application, which is Reasily if using Android and AZARDI if using a Desktop PC/Laptop.

The stages of making the Mathematics E-Module using the SIGIL application consist of 5 stages, including:

a. Insert HTML page

Before inserting an HTML page, we first arrange the teaching material file in Ms. Word. Furthermore, the file is in the Ms. Word format then converted into HTML format. We can insert the material file in HTML format into the HTML page which is the design of the Mathematical E-Module that we will develop. How to enter it is by clicking File $\rightarrow$ Open in the initial view of the SIGIL application, and then select the HTML file format that we want to enter. After the file is inserted, we can still edit the text that still has typos or spaces error. Besides material files, we can also insert image files into HTML E-module pages.

b. Colophons (author's notes)

Colophons are the author's notes, which are generally at the end of the module manuscript. It contains information about the place, time and copy of the manuscript. Colophons in digital books are the same as metadata.

c. Making a Cover Image.

We can make the Math E-Module cover by using graphic design applications, such as Adobe Photoshop and so on. The following is the Math E-Module cover that is used: 


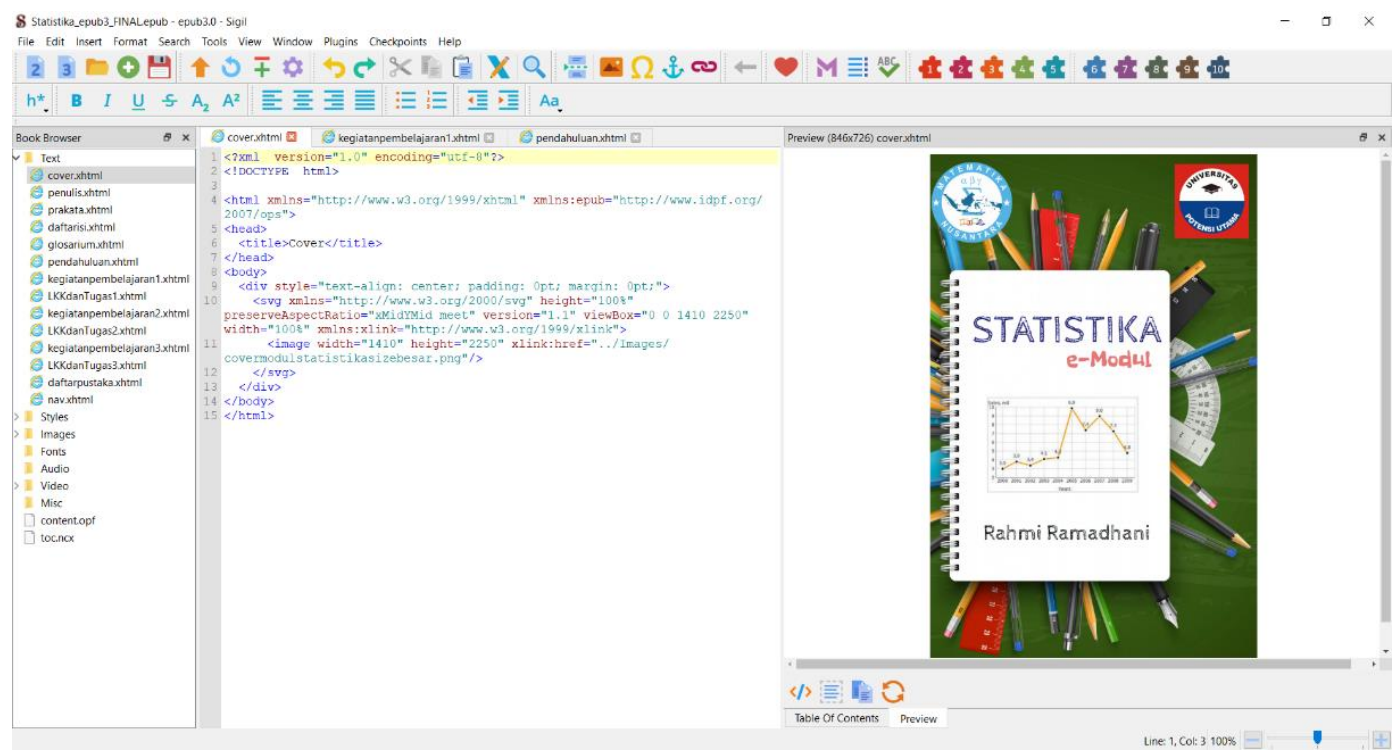

Figure 2. The Display of Cover Image on the Developed Mathematics E-Module in SIGIL Application

d. Indentation

Indentation is the portion of a paragraph that protrudes into the lines of a paragraph. Indenting is part of making a table of contents on the E-module. Table of contents is the main way for E-module users to navigate in EPUB documents. Users can directly open the part of the document you want to read using the table of contents without having to open each page.

e. Inserting Multimedia Files

Multimedia files such as teaching videos in MP4, WEBM and audios in MP3, WAV or OGG formats can be embedded in HTML pages (Muriel \& Galet, 2018). HTML display for inserting instructional videos in MP4 format can be seen as follows:

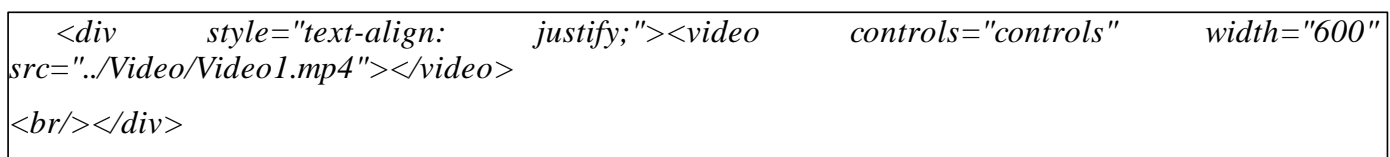

Figure 3. The Display of Code in the HTML Page to Insert MP4 Video in SIGIL Application

The name of the teaching video file in MP4 format that is saved must be the same as the name of the file inputted in the HTML page. 


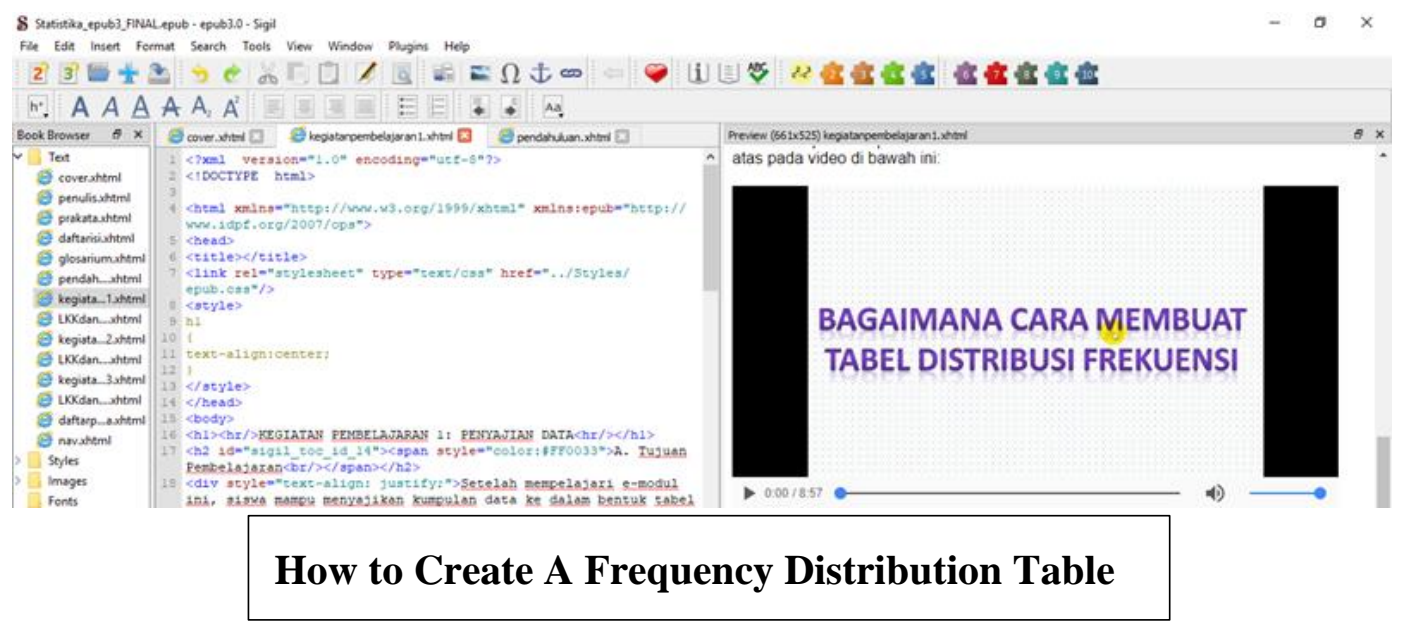

Figure 4. The Display of Teaching Video Files in MP4 Format on HTML Pages in the SIGIL Application

f. Compose Exercises and Evaluations

We can also create a special HTML page for the Exercise and Evaluation results page. In addition, we can make automatic assessments of exercises or evaluations that have been prepared if in the form of multiple-choice questions and can be adjusted to the KKM value that students must obtain. It is intended to aware students whether the results of their Exercise and Evaluation that had been done reach the KKM scores required under the 2013 curriculum.

\begin{tabular}{|c|c|}
\hline \multicolumn{2}{|c|}{ Prevew (6615525) lothan $2 \times$ xherl } \\
\hline \multicolumn{2}{|c|}{ G. Latihan 2} \\
\hline \multicolumn{2}{|c|}{ Kerjakan soal-soal berikut dengan memilih jawaban yang paling tepatl } \\
\hline \multicolumn{2}{|l|}{ Soal 1} \\
\hline \multicolumn{2}{|c|}{ Data yang diberikan dalam tabel distribusi frekuensi sebagai berikut: } \\
\hline Kelas & Frekuensi \\
\hline $20-29$ & 3 \\
\hline $30-39$ & 7 \\
\hline $40-49$ & 8 \\
\hline $50-59$ & 12 \\
\hline $60-69$ & 9 \\
\hline $70-79$ & 6 \\
\hline $80-89$ & 5 \\
\hline \multicolumn{2}{|c|}{ A. $\quad 49,5-\frac{40}{7}$} \\
\hline \multicolumn{2}{|c|}{ B. $49,5-\frac{36}{7}$} \\
\hline$\ldots \ldots$ & \\
\hline$f$ 담 If & \\
\hline
\end{tabular}

G. Exercise 2

Do the following questions by choosing the most appropriate answer!

\section{Question 1}

The data provided in the frequency distribution table are as follows:

\begin{tabular}{|c|c|}
\hline Class Interval & Frequency \\
\hline $20-29$ & 3 \\
$30-39$ & 7 \\
$40-49$ & 8 \\
$50-59$ & 12 \\
$60-69$ & 9 \\
$70-79$ & 6 \\
$80-89$ & 5 \\
\hline
\end{tabular}

The mode value of the data in the table above is:

A. $49,5-\frac{40}{7}$

Figure 5. The Display of Evaluation of Learning Outcomes in SIGIL Application

After the Mathematical E-Module was designed and developed in the EPUB3 format using the SIGIL application version 1.2.0 which called the prototype, the next step 
is to validate the contents of the developed E-Module prototype. Validation was carried out by two lecturers with educational technology expertise in mathematics and learning as well as two mathematics teachers who taught at the High School level. The results of the content validation carried out by experts can be seen in Table 1 below:

Table 1. Result of Content Validation by Experts

\begin{tabular}{cccl}
\hline $\begin{array}{c}\text { Content } \\
\text { (Expert) }\end{array}$ & Average & Category & \multicolumn{1}{c}{ Comments and Suggestion } \\
\hline $\begin{array}{c}\text { Material } \\
\text { (Lecturers) }\end{array}$ & 3,8 & Good & $\begin{array}{l}\text { Indicators of competency achievement } \\
\text { and basic competencies are displayed at } \\
\text { the beginning of each sub material. } \\
\text { The types of practice questions are } \\
\text { more varied and note the use of } \\
\text { appropriate spellings. }\end{array}$ \\
$\begin{array}{cccc}\text { (Teachers) } \\
\text { Design }\end{array}$ & 4,0 & Very Good & $\begin{array}{l}\text { Pay attention to the quality of the } \\
\text { instructional video that is inserted in } \\
\text { the E-Module. Give color variations to } \\
\text { the graphics and fonts of writing. } \\
\text { Improve the use of formulas, highlight } \\
\text { each formulation hence students focus } \\
\text { on it. }\end{array}$ \\
Design & 3,7 & Very Good & Good \\
(Teachers) & & &
\end{tabular}

Based on the validation results of the experts above, it can be concluded that the average validation results are in the "Good" category and have an average value of 3.77. This indicated that the prototype E-Module can be used in learning (after revisions according to the comments of experts). The next stage, the prototype E-Module is revised to later be called the final E-Module. This final e-module is used in mathematics learning, especially in statistical material for second-year senior high school students. Following the conditions and situations that occur today, that is the co-19 pandemic, the learning process is done online (e-learning); hence the use of EPUB3-based mathematical E-Module is very suitable for students to learn statistical material. The results of using EPUB3 based Mathematics E-Module for second-year students of Senior High School in Medan Sumatera Utara showed that 58\% of students felt helped in learning statistical material. Based on the results of the questionnaire given to 115 students in three senior high schools in the city of Medan, it was found that $58 \%$ of students were happy and helped by the EPUB3-based mathematics E-Module that had been developed. Students are also able to use the EPUB3 based E-Mathematics Module both using Reasily and using AZARDI. While $33 \%$ of students felt they were still unable to understand the material easily even though they were using EPUB3-based mathematics E-Modules and 9\% of students stated that they did not understand the use of EPUB3-based mathematics E-Modules and did not understand statistical material.

Based on the results of the questionnaire, it can be concluded that 67 students felt happy and helped in understanding statistical material in mathematics learning through the use of EPUB3-based mathematics E-Modules. Students also experience an increased motivation to learn, because the learning process uses more technology and communication media, such as mobile phones that have been a medium that is close to students (Jones, 2014; Parasuraman et al., 2017). The same results obtained by Hasbiyati et al. (2019) and Park et al. (2019) in their research, that the use of e-books developed using the SIGIL application helps students in learning the subject matter. 


\section{Discussion}

This study aims to develop a mathematical e-module in EPUB3 format using the SIGIL application. The use of the SIGIL application was chosen by researchers because the SIGIL application is easy to use. The programming language used is also commonly used, namely HTML. However, the difference with other e-modules developed using the SIGIL application is in the e-module format section. In this study, the e-module format was designed using EPUB3. The method used in this study is the ASSURE method which consists of 6 stages, that is analyze learners-state objectives; select methods, media and materials; utilize media and materials; require learner participant; evaluate and revise. In this article, the researcher only discusses the fourth step in the ASSURE method, which is the "utilize media and materials" stage.

The fourth step in the ASSURE method is the media and material development stage. In this study, the media and materials developed are e-modules of mathematics in statistical teaching material. The statistical teaching material discussed in the e-module includes the frequency distribution table, the size of the data centralization, the size of the data distribution and the size of the data presentation. The selection of teaching materials is adjusted to the teaching materials in class XI Senior High School students which refer to the 2013 Curriculum.

The first development stage is designing sub-material that will be used in the emath module, preparing teaching videos in MP4 format, collecting images relevant to the material and designing practice learning evaluation questions at the end of each teaching material chapter. At the end of the e-module is also assigned a final evaluation which covered the whole sub material that has been studied by students.

The second development stage is designing e-modules using the SIGIL application. The SIGIL application used is version 1.2.0 or the latest version. The difference with the previous version is one of them is the EPUB3 format display. The SIGIL application itself is often used by other researchers in developing digital teaching materials, such as emodules and e-books. Figueiredo \& Bidarra (2015) developed a game-book using the SIGIL application. After choosing the EPUB3 format, the next step is to change the file material that will be presented in the e-module into HTML format. This is done hence the material is more easily inserted on HTML pages in the SIGIL application. Meanwhile, to insert a video in MP4 format, it must be ensured that the file name in the video is the same as the name of the video file to be inserted in the HTML page of the SIGIL application. Designing e-modules using the SIGIL application requires the ability to use HTML Language. This is because all items that will be input are HTML languages.

The final stage of e-module development using the SIGIL application is finalizing the prototype e-module. Finalization is done by validating the experts in the field of mathematics learning technology (lecturers) and teachers who teach mathematics, especially statistical material. As explained earlier that based on the results of the validation obtained an average score of 3.77 (good category). These results indicated that the emodule as a whole can be used in online mathematics learning (after a revision process according to the results of the experts' review).

The use of e-modules in learning mathematics today is very necessary. This is related to the regulation of social distancing restrictions that cause all schools in Indonesia to carry out online learning processes (e-learning). The increasingly widespread impact of the pandemic covid-19 has resulted in face-to-face learning turning to online-based learning using a variety of online learning platforms, one of which is e-module. The results obtained after implementing e-modules in online mathematics learning, showed that more than half the number of student respondents felt delighted and was assisted when learning by using the e-modules. This is because e-modules can be accessed via the Android 
cellphone (using the Reasily application) and can also be accessed via a Laptop or Desktop PC (using the AZARDI application). Students can also work on practice and evaluation questions directly by choosing the right answer. The results of the assessment of practice questions can also be directly obtained by students. The use of e-modules using the SIGIL application helps students understand and learn the teaching material. Students also easily access e-modules anytime and anywhere (Liana et al., 2019). The use of e-modules using the SIGIL application also increases students' independence in learning (Alperi, 2019; Astuti \& Kusumajanto, 2017; Lamb \& Annetta, 2013) and supporting online-based learning programs (e-learning) during the covid-19 pandemic.

The development of an e-module based on SIGIL software with the EPUB3 format makes it easier for teachers to create more concise, appealing instructional materials that can be used anytime and anywhere, especially in Pandemic Covid-19. There is no research about using e-module based on SIGIL EPUB3 in mathematics learning in present condition. This finding is also verified by the statement of Pombo et al. (2012), Kuk et al. (2012) and Tobing et al. (2020) who found that learning using the E-Module not only made it simpler for students to learn the material but also provided new competencies for teachers in combining technology in the learning process. On the other hand, the use of the EModule in the teaching and learning phase increase the encouragement of students to study. The E-Module increases the metacognitive knowledge of what students know and what they may know about the subject being studied (Lee \& Osman, 2012). Based on that fact, we concluded that the SIGIL-based E-Module was able to organize a better line for the learning environment. The SIGIL interface is easy to learn, so that teachers with any field of expertise can develop e-modules well. This is the main advantage that the SIGIL application has and that which other e-module maker applications do not have. Rochsun \& Agustin (2020); Kusumaningtyas \& Suparman (2020) and Komikesari et al. (2020) also develop E-Module based on Flip PDF Professional for use in mathematics learning. Flip PDF Professional has many multimedia features, such as video, audio, and flash animation. These features different from SIGIL application features. Development e-module using SIGIL application, teacher do not need to create their flash animation in their module. Most teachers do not have more competencies to create animation with Macromedia flash. In the SIGIL application, the teacher can create their learning video and add it to their e-module. They can make their exercise form with automatic assessment in their e-module too. All the benefits in the SIGIL application help teacher to make a simple e-module only using one application and e-module can access by PC, Laptop, or Handphone.

Previous research using the e-module focused on SIGIL EPUB3 in current mathematics learning is not available. Before the Covid-19 scenario, the related studies that used e-module based on SIGIL implementation do more. The creation of SIGIL-based emodules and their use during the COVID-19 Pandemic in mathematics learning is therefore quite fitting. It is intended that, without reducing the student learning experience that is already obtained using SIGIL-based e-modules, the mathematics learning process carried out during the present pandemic will continue to be carried out.

\section{CONCLUSION}

Based on the results of research and discussion that has been presented previously, it can be concluded several things. First, the Mathematical E-Module developed based on EPUB3 and used the SIGIL application is valid and feasible to be applied in mathematics learning. Second, the SIGIL application as an E-Module making application is a good application to be used in developing digital-based learning modules or textbooks. Third, the use of E-Modules based on EPUB3 SIGIL provides new learning experiences and skills 
for students during the distance learning caused by Covid-19 pandemic. However, this study still has shortcomings and limitations, in which further research is, still needed relating to the effectiveness of a more specific and significant student learning outcomes improvement while using EPUB3-based mathematics E-Modules in learning.

\section{ACKNOWLEDGEMENT}

Great appreciation and gratitude are due to Ministry of Research and Technology of the Republic of Indonesia (Council of Research and National Innovation)-Deputy of Research Reinforcement and Development that has provided funding this research project (Research of Initiate Lecturer or PDP) with letter of decision No. 9/E1/KPT/2020.

\section{REFERENCES}

Al-Hariri, M. T., \& Al-Hattami, A. A. (2017). Impact of students' use of technology on their learning achievements in physiology courses at the University of Dammam. Journal of Taibah University Medical Sciences, 12(1), 82-85. https://doi.org/10.1016/j.jtumed.2016.07.004

Allen, J., Rowan, L., \& Singh, P. (2020). Teaching and teacher education in the time of COVID-19. Asia-Pacific Journal of Teacher Education, 48(3), 233-236. https://doi.org/10.1080/1359866X.2020.1752051

Alperi, M. (2019). Peran bahan ajar digital SIGIL dalam mempersiapkan kemandirian belajar peserta didik. Jurnal Teknodik, O(1), 99-110. https://doi.org/10.32550/teknodik.v0i1.479

Asrial, Syahrial, D. A. K., \& Anandari, Q. S. (2019). Digitalization of ethno constructivism based module for elementary school students. Jurnal Ilmu Pendidikan, 25(1), 33-41. https://doi.org/10.17977/um048v25i1p33-41

Astuti, O. W., \& Kusumajanto, D. D. (2017). Development of electronic book (e-book) EPUB-based for display course. Jurnal Pendidikan Bisnis Dan Manajemen, 3(2), $157-164$.

Audhina Kusumaningtyas, S., \& Suparman. (2020). E-Module design based mathematics PBL learning model to enhance creative thinking skills. International Journal of Scientific \& Technology Research, 9(3), 3518-3523. www.ijstr.org

Bawa, P. (2016). Retention in online courses: exploring issues and solutions-a literature review. SAGE Open, 6(1), 1-11. https://doi.org/10.1177/2158244015621777

Burroughs, N., Gardner, J., Lee, Y., Guo, S., Touitou, I., Jansen, K., \& Schmidt, W. (2019). A Review of the Literature on Teacher Effectiveness and Student Outcomes. In Teaching for Excellence and Equity. Springer International Publishing. https://doi.org/10.1007/978-3-030-16151-4_2

Daniel, S. J. (2020). Education and the COVID-19 pandemic. Prospects, 49, 1-6. https://doi.org/10.1007/s11125-020-09464-3

Darma, R. S., Setyadi, A., Wilujeng, I., Jumadi, \& Kuswanto, H. (2019). Multimedia learning module development based on SIGIL software in physics learning. IOP Conf. Series: Journal of Physics: Conf. Series 1233, 1-7. https://doi.org/10.1088/1742-6596/1233/1/012042

Dhawan, S. (2020). Online learning: a panacea in the time of COVID-19 crisis. Journal of Educational Technology Systems, $49(1), \quad$ 5-22. https://doi.org/10.1177/0047239520934018 
Fauziah, I. Z., Sutrisno, \& Suwarni. (2016). Pengembangan e-modul berbasis adobe flash CS6 pada mata pelajaran penataan barang dagang. Jurnal Pendidikan Bisnis Dan Manajemen, 2(2), 154-159.

Figueiredo, M., \& Bidarra, J. (2015). The development of a gamebook for education. Procedia Computer Science, 67, 322-331. https://doi.org/10.1016/j.procs.2015.09.276

Fonda, A., \& Sumargiyani, S. (2018). The developing math electronic module with scientific approach using kvisoft flipbook maker pro for XI grade of senior high $\begin{array}{lllll}\text { school students. Infinity Journal, } & 7(2), & 109 .\end{array}$ https://doi.org/10.22460/infinity.v7i2.p109-122

Freiman, V., Polotskaia, E., \& Savard, A. (2017). Using a computer-based learning task to promote work on mathematical relationships in the context of word problems in early grades. ZDM - Mathematics Education, 49(6), 835-849. https://doi.org/10.1007/s11858-017-0883-3

Grabinski, K., Kedzior, M., Krasodomska, J., \& Herdan, A. (2020). Embedding e-Learning in accounting modules: the educators' perspective. Education Sciences, 10(97), 1-19. https://doi.org/10.3390/educsci10040097

Hamzah, I., \& Mentari, S. (2017). Development of accounting e-module to support the scientific approach of students grade vocational high school. Journal of Accounting and Business Education, 2(1), 78-88.

Hasbiyati, H., Sudiarti, D., \& Hikamah, S. R. (2019). The effectiveness of using smartphone-based e-book in increasing students' learning outcomes in science learning. IOP Conference Series: Earth and Environmental Science, 243, 12071. https://doi.org/10.1088/1755-1315/243/1/012071

Jaenudin, A., Baedhowi, \& Murwaningsih, T. (2017). The effectiveness of the e-Module of economics learning on problem-based learning used to improve students' learning outcomes. Advances in Social Science, Education and Humanities Research (ASSEHR) 158, 30-36.

Jones, T. (2014). Students' cell phone addiction and their opinions. The Elon Journal of Undergraduate Research in Communications, 5(1), 74-80.

Kim, D., \& Downey, S. (2016). Examining the use of the ASSURE model by K-12 teachers. Computers in the Schools, 33(3), 153-168. https://doi.org/10.1080/07380569.2016.1203208

Komikesari, H., Mutoharoh, M., Dewi, P. S., Utami, G. N., Anggraini, W., \& Himmah, E. F. (2020). Development of e-module using flip pdf professional on temperature and heat material. Journal of Physics: Conference Series, 1572(1), 12017. https://doi.org/10.1088/1742-6596/1572/1/012017

Kuk, K., Milentijević, I., Rančić, D., \& Spalević, P. (2012). Pedagogical agent in multimedia interactive modules for learning - MIMLE. Expert Systems with Applications, 39(9), 8051-8058. https://doi.org/10.1016/j.eswa.2012.01.138

Lamb, R. L., \& Annetta, L. (2013). The use of online modules and the effect on student outcomes in a high school chemistry class. Journal of Science Education and Technology, 22(5), 603-613. https://doi.org/10.1007/s10956-012-9417-5

Lestari, A.P., et al. (2020). Development of stop motion mathematics animation. Formatif: Jurnal Ilmiah Pendidikan MIPA, 10 (2), 77-90. http://dx.doi.org/10.30998/formatif.v11i1.6563

Liana, Y. R., Ellianawati, \& Hardyanto, W. (2019). Pengembangan e-Modul interaktif berbasis android menggunakan sigil software pada materi listrik dinamis. Seminar Nasional Pascasarjana Universitas Negeri Semarang, 926-932. 
Linda, R., Herdini, H., S, I. S., \& Putra, T. P. (2018). Interactive e-module development through chemistry magazine on kvisoft flipbook maker application for chemistry learning in second semester at second grade senior high school. Journal of Science Learning, 2(1), 21-25. https://doi.org/10.17509/jsl.v2i1.12933

Matanluk, O., Mohammad, B., Kiflee, D. N. A., \& Imbug, M. (2013). The effectiveness of using teaching module based on radical constructivism toward students learning process. Procedia - Social and Behavioral Sciences 90, 607-615. https://doi.org/10.1016/j.sbspro.2013.07.132

Muriel, F. J., \& Galet, C. (2018). Editing ePub3 for blended learning in mathematics. Proceedings, 1-7. https://doi.org/10.3390/proceedings 2211362

Murphy, M. P. A. (2020). COVID-19 and emergency e-learning: consequences of the securitization of higher education for post-pandemic pedagogy. Contemporary Security Policy, 41(3), 492-505. https://doi.org/10.1080/13523260.2020.1761749

Nursolekah, S., \& Suparman. (2019). Design of mathematics learning module based on problem based learning to improve critical thinking ability students. International Journal of Scientific \& Technology Research, 8(12), 2608-2616.

Parasuraman, S., Sam, A., Yee, S. K., Chuon, B. C., \& Ren, L. (2017). Smartphone usage and increased risk of mobile phone addiction: A concurrent study. International $\begin{array}{llll}\text { Journal of Pharmaceutical Investigation, } & 7(3), & 125 .\end{array}$ https://doi.org/10.4103/jphi.jphi_56_17

Park, J. H., Kim, H. Y., \& Lim, S. B. (2019). Development of an electronic book accessibility standard for physically challenged individuals and deduction of a production guideline. Computer Standards and Interfaces, 64, 78-84. https://doi.org/10.1016/j.csi.2018.12.004

Pradina, L. P., \& Suyatna, A. (2018). Atom core interactive electronic book to develop self efficacy and critical thinking skills. TOJET: The Turkish Online Journal of Educational Technology, 17(1), 17-23.

Qurat-ul-Ain, Q.-A., Shahid, F., Aleem, M., Islam, M., Iqbal, M., \& Yousaf, M. (2019). A review of technological tools in teaching and learning computer science. Eurasia Journal of Mathematics, Science and Technology Education, 15(11), 1-17. https://doi.org/10.29333/ejmste/109611

Ramadhani, R. (2020). Desain Pembelajaran Matematika Berbasis TIK: Konsep dan Penerapan (J. Simarmata (ed.)). Yayasan Kita Menulis.

Ramadhani, R., \& Fitri, Y. (2020a). Pengembangan e-modul matematika berbasis model flipped-blended learning. Genta Mulia, 11(2), 150-163.

Ramadhani, R., \& Fitri, Y. (2020b). Validitas e-modul matematika berbasis EPUB3 menggunakan analisis rasch model. Jurnal Gantang, 5(2), 95-111. https://doi.org/10.31629/jg.v5i2.2535

Ramadhani, R., Umam, R., Abdurrahman, A., \& Syazali, M. (2019). The effect of flippedproblem based learning model integrated with LMS-google classroom for senior high school students. Journal for the Education of Gifted Young Scientists, 7(2), 137-158. https://doi.org/10.17478/jegys.548350

Rochsun, \& Agustin, R. D. (2020). The development of e-module mathematics based on contextual problems. European Journal of Education Studies, 7(10), 400-412. https://doi.org/10.46827/ejes.v7i10.3317

Sadeghi, M. (2019). A shift from classroom to distance learning: advantages and limitations. International Journal of Research in English Education, 4(1), 80-88.

Sari, A. S. (2016). Pengembangan buku digital melalui aplikasi SIGIL pada mata kuliah cookies dan candys. JURNAL SCIENCE TECH, 1(2), 46-54. 
Setyaningrum, W. (2018). Blended learning: does it help students in understanding mathematical concepts? Jurnal Riset Pendidikan Matematika, 5(2), 244-253. https://doi.org/10.21831/jrpm.v5i2.21428

Syahrul, S. A., Murni, A., \& Siregar, S. N. (2019). Implementation of problem based Learning model to improve student's mathematical problem solving skill at class VIIIA 2 MTs darul hikmah pekanbaru. JOM FKIP, 6(1), 1-12.

Tobing, H. E. L., Somakim, \& Susanti, E. (2020). The use of electronic modules designed using sigil in learning the distance in geometry. Advances in Social Science, Education and Humanities Research 513, 640-647.

Tsai, T., Lin, J., \& Lin, L. (2017). A flip blended learning approach for ePUB3 eBookbased course design and implementation. Eurasia Journal of Mathematics, Science and Technology Education, 14(1), 123-144. https://doi.org/10.12973/ejmste/79629

Üzela, D., \& Özdemira, E. (2012). The effects of problem-based e-learning on prospective teachers' achievements and attitudes towards learning mathematics. Procedia-Social and Behavioral Sciences 55, 1154-1158. https://doi.org/10.1016/j.sbspro.2012.09.609

Wahyuni, S. I., Noer, A. M., \& Linda, R. (2018). Development of electronic module using kvisoft flipbook maker application on the chemical equilibirium. Proceeding of the 2nd URICES, 2018, 178-189.

Zhang, W., Wang, Y., Yang, L., \& Wang, C. (2020). Suspending classes without stopping learning: china's education emergency management policy in the COVID-19 outbreak. Journal of Risk and Financial Management, 13(55), 1-6. https://doi.org/10.3390/jrfm13030055 